\title{
COVID-19, HCT and wine
}

\author{
Shaun R. McCann ${ }^{1}$
}

Received: 22 April 2020 / Revised: 24 April 2020 / Accepted: 27 April 2020 / Published online: 6 May 2020

(c) Springer Nature Limited 2020

'I find friendship to be like wine: raw when new; ripened with age the true old man's milk and restorative cordial'. Letter from Thomas Jefferson (1743-1826, 3rd president of the United States) to his friend and physician Dr Benjamin Rush [1] signatory of the United States Declaration of Independence.

The COVID-19 pandemic has made a difficult job more difficult for haemopoietic cell transplant (HCT) doctors and undoubtedly increases anxiety levels among prospective patients and their donors. The European Society for Blood and Marrow Transplantation (EBMT) [2] and the American Society of Transplantation and Cellular Therapy Infectious Diseases Special Interest Group (ASTCT) [3] have addressed the problem and issued recommendations. Likewise, King's College Hospital, London, UK, has issued guidelines for patients undergoing HCT for Severe Aplastic Anaemia [4] as have the American Society for Hematology (ASH) [5], the EBMT [6] and the Haematology Society of Australia and New Zealand [7].

In general, the guidelines recommend that all nonessential transplants should be postponed (easier said than done), donors and patients should avoid all possible infection with COVID-19 and avoid travelling to areas designated as high-risk and all products should be cryopreserved. Un-related transplants are further complicated by the paucity of air flights. In HCT units, COVID-19 illness in staff may deplete health care worker numbers. At the time of writing only one HCT recipient contracted COVID-19 infection in Ireland and happily made a full recovery (personal communication Dr E Conneally, National Stem Cell Transplant, Unit, St James' Hospital, Dublin). At the moment there is no specific treatment for COVID-19

Shaun R. McCann

shaunrmccann@gmail.com

1 Haematology Emeritus, Trinity College, University of Dublin, Dublin, Ireland infection but there are numerous drug trials taking place. Ultimately a vaccine is eagerly awaited.

Countries have varied in their attempts to contain the impact of the virus with a wide range of success/failure. One of the better outcomes was in New Zealand where prime minister, Jacinda Ardren, reported a remarkably low total of 12 COVID-related deaths. 'We acted hard and fast' she said.

Has the COVID-19 pandemic affected the wine trade? It most certainly has. Although wine sales have increased from off-licences (it's one way of passing the time) in many countries, there are specific and sometimes unexpected problems. Grape picking is obviously a seasonal issue Fig. 1 and, in many continents, the harvest depends on migrant/seasonal workers. In many European countries and in the United States migrant workers are essential as native populations do not want to partake in what is described as poorly paid and back-breaking work. The grape picking season will not begin until late August/ September so it's a little early to predict the extent of possible difficulties.

Vitis vinifera, by far the most common species of vines in the world, are hermaphrodite plants and therefore don't need bees to pollinate them. However, many fruit crops

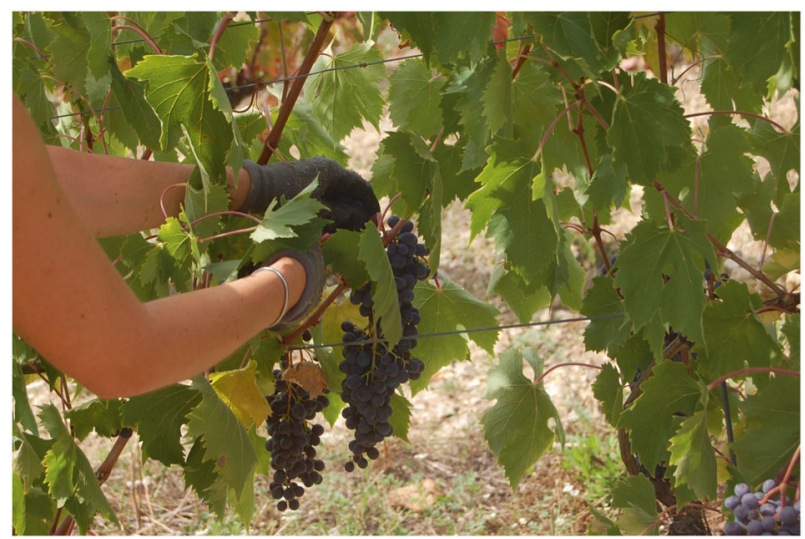

Fig. 1 Hand harvesting in happier times. Photograph Shaun McCann. 


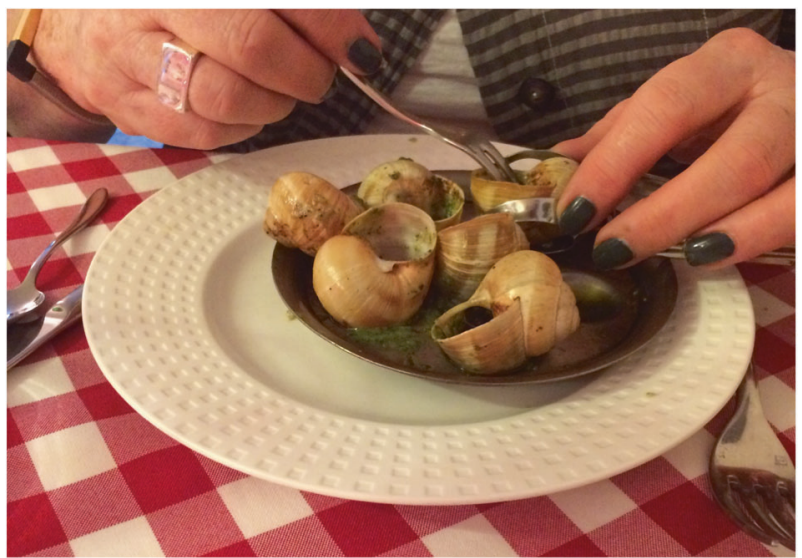

Fig. 2 Eating in a restaurant in Paris, 2016. Photograph Shaun McCann.

require pollination and the relative absence of bees poses problems. According to Laura Battle writing in the weekend FT [8] the global spread of coronavirus has had an enormous impact on consumers and farmers. As with grapes many farmers rely on seasonal/migrant fruit pickers. She says that one of Britain's largest suppliers chartered a flight from Romania for 150 seasonal pickers. In Ireland a large supplier chartered a plane and brought 189 fruit pickers from Bulgaria. Everybody understands the need to pick fruit when it is ripe, but adequate quarantine and living accommodation must be provided. I have not personally examined the living conditions of seasonal workers but would be surprised if they are pristine and social distancing possible. A representative of a large fruit supplier in Ireland claimed that it takes 6 months to train a fruit-picker. If we can train medical students to become doctors in 4-5 years this seems unlikely to me. Another side of the coin is that many seasonal workers play a very important role in the economy of their country of origin by sending money home like thousands of Italians and Irish did in the early 20th century.

Writing in the same newspaper, Emiko Terazono (London, UK) and Benjamin Parkin (New Delhi, India) [9], highlight the fact that border closures and visa restrictions are threatening food production by limiting movement of bees, which are trucked through agricultural areas. There is also a shortage of truck drivers. They claim that the United States and Canada import queen bees from Australia, New Zealand, Mexico and Chile.
Although bees may not be important to wine farmers, the closure of restaurants and the problems of importing seasonal/migrant grape pickers impose difficulties in spite of the fact that in some instances seasonal/migrant workers live in the country where they are needed. Although supermarkets continue to be outlets for wine sales, the closure of restaurants is a major concern for the wine trade.

As grape harvesting occurs in August/September in the northern hemisphere we can hope that the pandemic may be controlled by then, and grapes can be harvested safely so that we may be able to enjoy a glass of wine in our local restaurant again Fig. 2.

\section{Compliance with ethical standards}

Conflict of interest The author declares that they have no conflict of interest.

Publisher's note Springer Nature remains neutral with regard to jurisdictional claims in published maps and institutional affiliations.

\section{References}

1. Hailman J. Thomas Jefferson on Wine. USA: The University Press of Mississippi; 2006. p 320.

2. Ljungman P, Styczynski J, Milkulska M. Coronavirus disease. COVID-19: EBMT recommendations update. https://www.ebmt. org/covid-19-and-bmt. Accessed 16 Mar 2020.

3. Waghmare A, Boeckh M, Chemaly F, Singh Dadwal S, Papanicolaou GA, Pergam S Interim guidelines for COVID-19 management in Hematopoietic cell transplant and cellular therapy patients. Version 1. On behalf of the American Society of Transplantation and Cellular Therapy Infectious Diseases Special Interest Group. Accessed 09 Mar 2020.

4. King's College Hospital guidelines for adult aplastic anaemia/bone marrow failure patients during the COVID-19 outbreak. 14/4/20 version.

5. The American Society for Hematology (ASH). Aplastic anemia patients. https://www.hematology.org/covid-19/covid-19-and-apla stic-anemia. Accessed 22 Apr 2020.

6. EBMT. https://www.ebmt.org/ebmt/documents/covid-19-bone-ma rrow-failure-and-pnh. Accessed 22 Apr 2020.

7. Weinkove R, McQuiliten Z, Blythe E, Cheng AC, Conyers R, Crane $M$, et al. Managing haematology and oncology patients during the COVID-19 pandemic: interim consensus guidance. Version 3.0. Med. J Aust. 2020;212:1.

8. Battle L. A bitter harvest begins for farmers. London, UK: Financial Times Ltd; 2020. Weekend FT April 18/19.

9. Terazono E, Parkin B. Crop farmers stung as bees struggle to pollinate under curbs. London, UK: Financial Times Ltd; 2020. Weekend FT April 18/19. 